\author{
K.T. Rustembekov, Ye.S. Lazareva \\ Ye.A. Buketov Karaganda State University \\ (E-mail: rustembekov_kt@mail.ru)
}

\title{
Tellurite $\mathrm{HoCaTeO}_{4.5}$ : Synthesis and Radiographic Characteristics
}

\begin{abstract}
The article shows the possibility of synthesizing new double holmium-calcium tellurite by solid phase method from oxides of holmium (III), tellurium (IV) and calcium carbonate. X-ray analysis shows that tellurite $\mathrm{HoCaTeO}_{4.5}$ crystallizes in the tetragonal structure. The parameters of the tellurite's unit cell, X-ray and pycnometric densities were determined by X-ray analysis as well.
\end{abstract}

Key words: holmium tellurite-calcium, X-ray analysis, syngony, unit cell parameters.

The discovery of high-temperature superconductivity in 1986 gave a powerful impetus to the development of solid state chemistry. Due to this fact metal oxide systems with a perovskite-like structure are of great interest.

Compounds of rare earth metal oxides possess a unique combination of electrical, magnetic, thermal, optical, and other properties due to the peculiarities of the electronic structure of lanthanides and can find extensive use in modern microelectronics and many fields of new technology to create multi-purpose systems [1].

Double tellurites, consisting of rare earth elements, alkali and alkaline earth metals, produce some theoretical and practical interest [2-4].

In this context the aim of this work is the synthesis and investigation of radiographic characteristics of tellurite $\mathrm{HoCaTeO}_{4.5}$.

The starting components for the synthesis were oxides of holmium (III), tellurium (IV) and calcium carbonate («reagent grade») in a stoichiometric ratio. Stoichiometric amounts of starting materials were thoroughly grinded in an agate mortar. Then material was placed in alundum crucibles and subjected to heat treatment for the solid-phase interaction in air in the Silit furnace. The following heat treatment regime was used: annealing for 15 hours at a temperature of $400{ }^{\circ} \mathrm{C}, 20$ hours at a temperature of $800^{\circ} \mathrm{C}$ with occasional grinding in a mortar; and further annealing for 23 hours at a temperature of $1200^{\circ} \mathrm{C}$ with periodic grinding of compounds; final annealing step within 10 hours at a temperature of $400{ }^{\circ} \mathrm{C}$ to produce a stable compound at low temperatures.

Formation of the equilibrium composition of the compound was monitored by X-ray analysis at the DRON 2.0 using $\mathrm{CuK}_{\alpha}$ that is radiation filtered with Ni-filter $(U=30 \mathrm{kV}, I=10 \mathrm{~mA}$, the range of the pulse counter 1000 counts $/ \mathrm{s}$, rotational speed counter $2 \% \mathrm{~min}$, the time constant $\tau=5$, the angular $2 \theta$ range from 10 to $90^{\circ}$ ). The roentgenogram of the synthesized tellurite is presented in Figure 1.

Based on data from X-ray diffraction of the compound (Fig. 1), the intensity of the diffraction peaks was estimated. Indexing of the X-ray picture of the test compound powder was determined by homology [5].

Reliability of indexing was controlled by satisfactory agreement between the experimental and calculated values $\left(10^{4} / d^{2}\right)$, as well as the consistency of the values of X-ray and pycnometric densities of the test compound. Toluene of analytical grade was selected as an indifferent fluid. Toluene is chemically inert to the test compound and wets an agent reasonably well. Pycnometric density tellurite was measured in a 3-ml pycnometer. The density of the analyte was measured 5 times by the known procedure [6].

The following operations were performed consistently. The mass of the empty pycnometer $M_{0}$ was determined. Then mass of the pycnometer filled with distilled water $M_{1}$ was found. Further pycnometer was filled with toluene and its mass $M_{2}$ was determined. Then the test substance was placed in a pycnometer and its mass $M_{3}$ was measured. Finally pycnometric liquid was placed in the pycnometer with the powder and its mass $M_{4}$ was determined. 


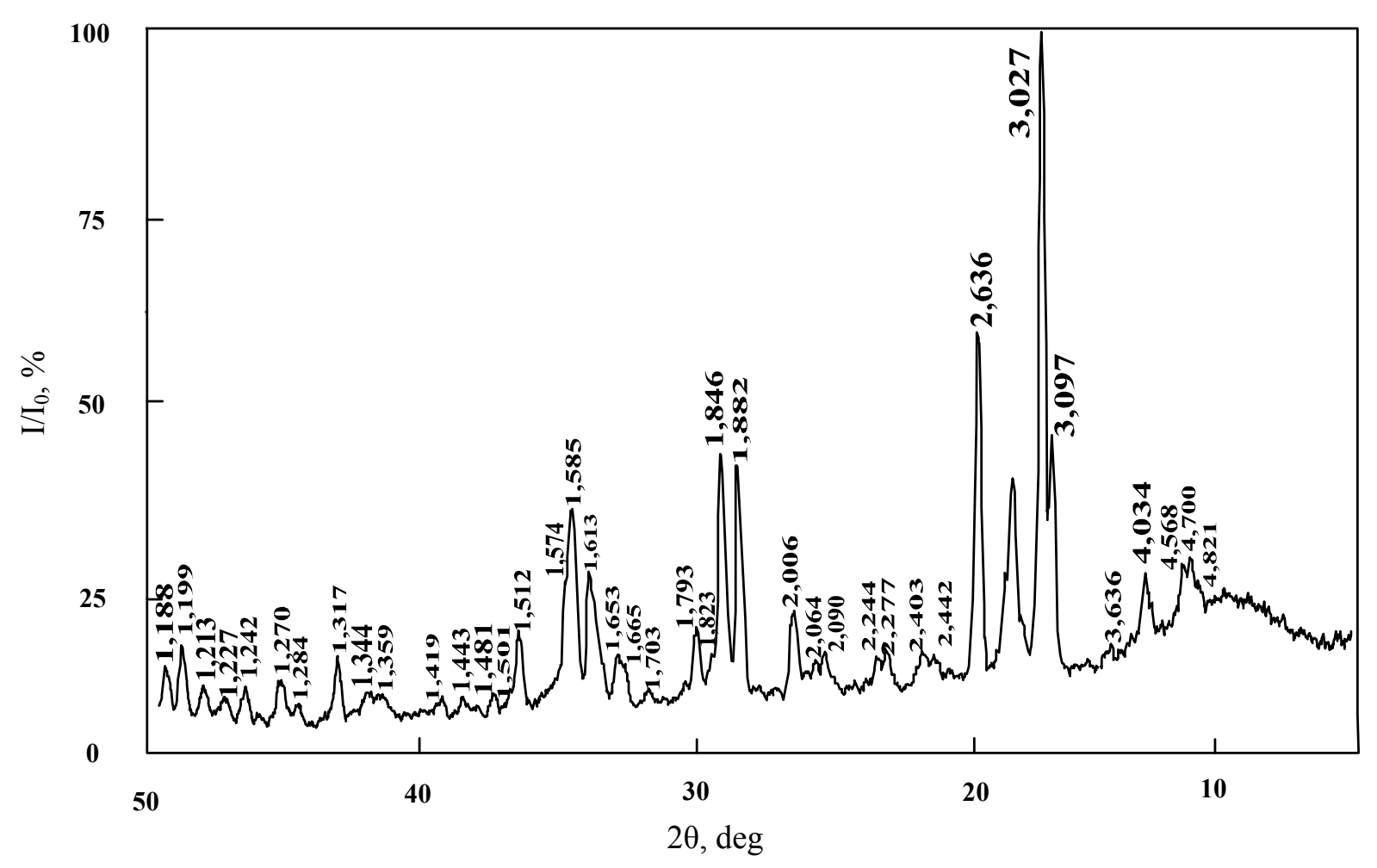

Figure 1. X-ray diffraction of the synthesized double- tellurite $\mathrm{HoCaTeO}_{4.5}$

The density of the test sample is found by the formula

$$
\rho_{\text {pycn. }}=\frac{M_{3}-M_{0}}{\frac{M_{1}-M_{0}}{\rho_{1}}-\frac{M_{4}-M_{3}}{\rho_{2}}},
$$

where $\rho_{1}$ is density of water at $20^{\circ} \mathrm{C}\left(0,9971 \mathrm{~g} / \mathrm{cm}^{3}\right) ; \rho_{2}$ is pycnometric density of liquid defined by the formula

$$
\rho_{2}=\frac{M_{2}-M_{0}}{M_{1}-M_{0}} \cdot \rho_{1} .
$$

X-ray density $\left(\rho_{\text {rad. }}\right)$ of the test compound was calculated by the formula

$$
\rho_{\mathrm{rad} .}=\frac{1,66 \cdot M_{r} \cdot Z}{V^{0}},
$$

where $M_{r}$ is the molecular weight of the unknown substance; $Z$ is the number of formula units; $V^{0}$ is volume of the cell.

The unit cell volume $\left(V^{0}\right)$ of the test compound was determined by the syngony:

- for the cubic syngony:

- for the tetragonal syngony:

$$
V^{0}=a^{3}
$$

$$
V^{0}=a^{2} c
$$

- for the hexagonal syngony:

$$
V^{0}=0,86 a^{2} c
$$

- for the rhombic syngony:

$$
V^{0}=a b c .
$$

Table 1 shows the results of indexing X-ray diffraction of the test compound powder. 
Indexing of radiographs of synthesized tellurite $\mathrm{HoCaTeO}_{4.5}$

\begin{tabular}{|c|c|c|c|c|}
\hline$I / I_{0}, \%$ & $d, \AA$ & $10^{4} / d^{2}$ exp. & $h k l$ & $10^{4} / d^{2}{ }_{\text {calc. }}$ \\
\hline 13 & 4,821 & 430 & 004 & 423 \\
\hline 17 & 4,7 & 452 & 212 & 448 \\
\hline 15 & 4,034 & 614 & 030 & 616 \\
\hline 37 & 3,097 & 1042 & 304 & 1039 \\
\hline 100 & 3,027 & 1091 & 400 & 11995 \\
\hline 10 & 2,897 & 1191 & 411 & 1233 \\
\hline 31 & 2,839 & 1240 & 330 & 1277 \\
\hline 17 & 2,792 & 1283 & 305 & 1432 \\
\hline 54 & 2,636 & 1439 & 219 & 2484 \\
\hline 12 & 2,006 & 2485 & 319 & 2826 \\
\hline 33 & 1,882 & 2823 & 526 & 2938 \\
\hline 34 & 1,846 & 2935 & 631 & 3108 \\
\hline 11 & 1,793 & 3110 & 714 & 3847 \\
\hline 19 & 1,613 & 3843 & 730 & 3972 \\
\hline 28 & 1,585 & 3980 & 627 & 4035 \\
\hline 18 & 1,574 & 4036 & 716 & 4375 \\
\hline 12 & 1,512 & 4374 & 5765 & 5771 \\
\hline
\end{tabular}

A satisfactory agreement between the experimental and calculated values $10^{4} / \mathrm{d}^{2}$, given in the Table 1 , as well as the consistency of the values of the X-ray and pycnometric densities of the test tellurite (Table 2) confirms the correctness of the indexing of the X-ray picture of the test compound.

Figure 2 shows the bar radiograph of the synthesized double tellurite $\mathrm{HoCaTeO}_{4.5}$ and starting materials. Comparison of these data shows that there are no peaks of starting compounds in the tellurite synthesized. Thus, new compound holmium-calcium double tellurite $\mathrm{HoCaTeO}_{4.5}$ was obtained as a result of solidphase synthesis.
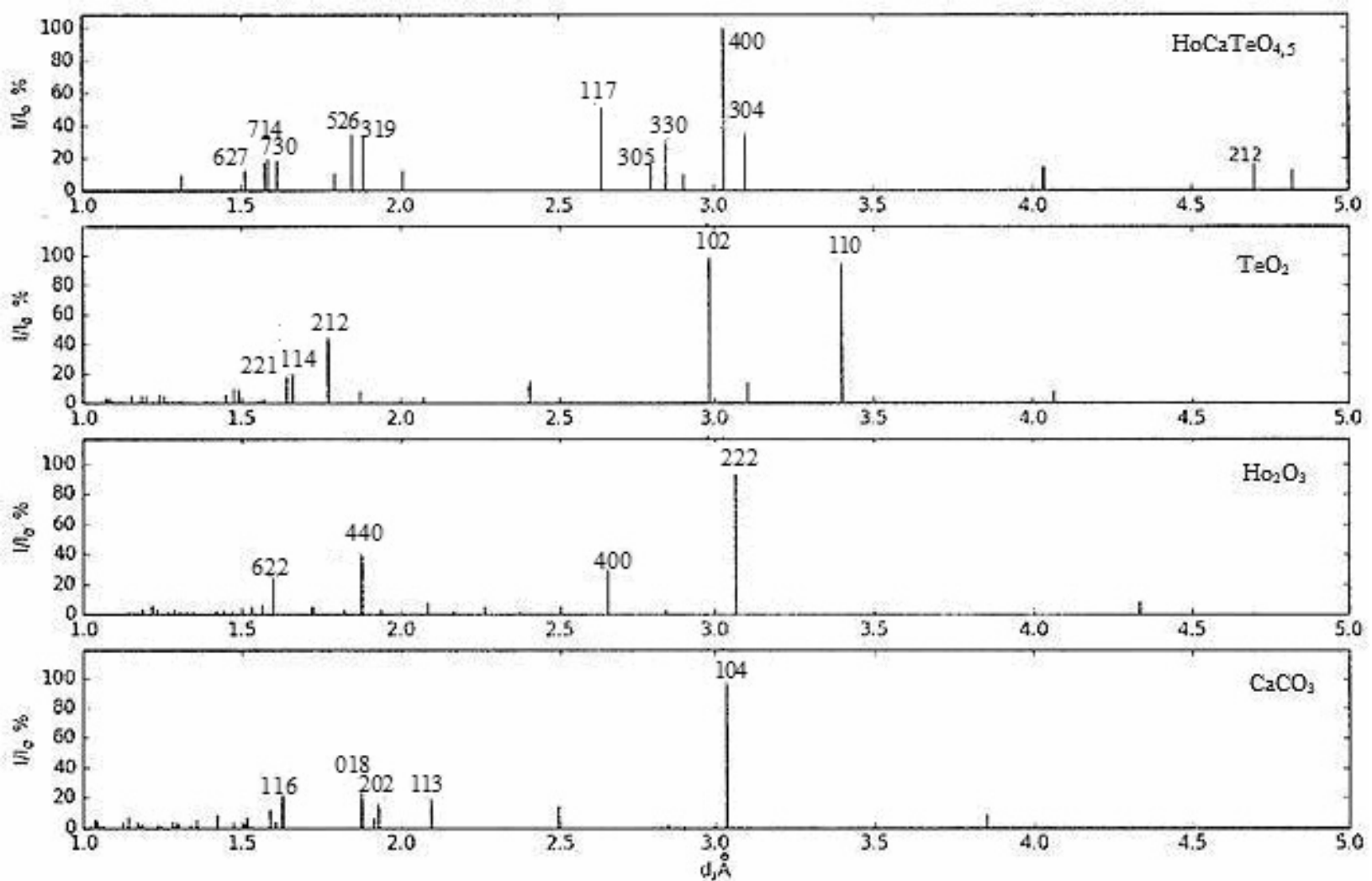

Figure 2. Radiographs of $\mathrm{HoCaTeO}_{4.5}$ and starting compounds with plane indices $(h k l)$ 
As can be seen from the Table 1 , the experimental and calculated values $\left(10^{4} / \mathrm{d}^{2}\right), \mathrm{X}$-ray and pycnometric densities (Table 2) are in a good agreement with each other, confirming the accuracy and correctness of the indexing results. Data obtained suggest that the compound $\mathrm{HoCaTeO}_{4.5}$ crystallizes in a tetragonal syngony and has a unit cell parameters which are shown in the Table 2.

Table 2

Type of syngonies and the unit cell parameters of the $\mathrm{HoCaTeO}_{4.5}$

\begin{tabular}{|c|c|c|c|c|c|c|c|c|}
\hline \multirow{2}{*}{ Compound } & \multirow{2}{*}{$\begin{array}{c}\text { A type } \\
\text { syngonies }\end{array}$} & \multicolumn{2}{|c|}{ The lattice parameters, $\AA$} & \multirow{2}{*}{$V^{0}, \AA^{3}$} & \multirow{2}{*}{$V_{\text {e.cell }}^{0}, \AA^{3}$} & \multirow{2}{*}{ Z } & \multicolumn{2}{|c|}{ Density, $\mathrm{g} / \mathrm{cm}^{3}$} \\
\hline & & $a$ & $c$ & & & & Radiog. & Pycnom. \\
\hline $\mathrm{HoCaTeO}_{4.5}$ & The tetrag. & 12,08 & 19,45 & 2839,92 & 88,75 & 32 & 7,56 & $7,22 \pm 0,34$ \\
\hline
\end{tabular}

Thus, new double tellurite of holmium-calcium $\mathrm{HoCaTeO}_{4.5}$ was synthesized by the solid-phase method. X-ray diffraction was used to determine the type of its syngony and the unit cell parameters. The X-ray diffraction investigation shows that the synthesized tellurite crystallized in a structural type of distorted perovskite $\mathrm{P}_{\mathrm{m}} 3_{\mathrm{m}}$. It allows to suggest that this compound can possess unique electrophysical properties.

Radiographic features of a new tellurite can be the source of information for basic reference books and information databases and produce interest for chemical informatics.

\title{
References
}

1 Набока М.Н., Палатник Л.С., Шевченко В.Я. Структура и свойства тонких пленок на основе соединений редкоземельных металлов // Журн. ВХО. - 1981. - Т. 26, № 6. - С. 31.

2 Rustembekov K.T., Dyusekeeva A.T. Tellurites of some $s-f$ elements: Synthesis, X-Ray Diffraction, and Electrophysical Properties // Russ. J. Gen. Chem. - 2012. — Vol. 82, No. 8. - P. 1357-1360.

3 Rustembekov K.T., Dyusekeeva A.T., Fomin V.N. Heat Capacity and thermodynamic functions of cerium tellurites in the range of 298.15-673 K // Russ. J. Phys. Chem.A. - 2015. - Vol. 89, No. 2. - P. 175-179.

4 Rustembekov K.T., Dyusekeeva A.T., Bekturganova A.Zh., Kasenov B.K., Fomin V.N. Heat Capacity and Thermodynamic Functions of Thulium Tellurites in the Range of 298.15-673 K // Russ. J. Phys. Chem. A. — 2016. — Vol. 90, No. 2. — P. $263-266$.

5 Ковба Л.М., Трунов В.К. Рентгенофазовый анализ. - М.: Изд-во МГУ, 1976. - 256 с.

6 Кивилис С.С. Техника измерений плотности жидкостей и твердых тел. - М.: Стандартгиз, 1959. - $191 \mathrm{c.}$

\section{К.Т. Рүстембеков, Е.С. Лазарева}

\section{НоСаTеО $_{4,5}$ теллуриті: синтезі және рентгенографиялық сипаттамалары}

\begin{abstract}
Мақалада қатты фазалық әдіспен гольмий (III), теллур (IV) оксидтері мен кальций карбонатының әрекеттесуі нәтижесінде жаңа гольмий-кальций қос теллуритін алудың мүмкіндігі көрсетілген. Рентгенфазалық әдіспен $\mathrm{HoCaTeO}_{4.5}$ теллуритінің тетрагональді сингонияда кристалданатыны, сондай-ақ оның элементар ұяшығының көрсеткіштері, рентгендік және пикнометрлік тығыздықтары анықталған.
\end{abstract}

\section{К.Т. Рустембеков, Е.С. Лазарева}

\section{Теллурит НоСаТеО 4.5 : синтез и рентгенографические характеристики}

В статье показана возможность синтеза нового двойного теллурита гольмия-кальция твердофазным способом из оксидов гольмия (III), теллура (IV) и карбоната кальция. Методом рентгенофазового анализа определено, что теллурит $\mathrm{HoCaTeO}_{4.5}$ кристаллизуется в тетрагональной сингонии, а также установлены параметры его элементарной ячейки, рентгеновские и пикнометрические плотности.

\section{References}

1 Naboka M.N., Palatnik L.S., Shevchenko V.Ya. J. ACS, 1981, 26, 6, p. 31.

2 Rustembekov K.T., Dyusekeeva A.T. Russ.J.Gen.Chem., 2012, 82, 8, p. 1357-1360. 
3 Rustembekov K.T., Dyusekeeva A.T., Fomin V.N. Russ.J.Phys.Chem.A., 2015, 89, 2, p. 175-179.

4 Rustembekov K.T., Dyusekeeva A.T., Bekturganova A.Zh., Kasenov B.K., Fomin V.N. Russ.J.Phys.Chem.A., 2016, 90, 2 , p. 263-266.

5 Kovba L.M., Trunov V.K. X-Ray Phase Analysis, Moscow: Moscow State Univ. Publ., 1976, 256 p.

6 Kivilis S.S. Appliances density measurements of liquids and solids, Moscow: Standartgiz, 1959, 191 p. 